\title{
PENGOLAHAN IKAN CAKALANG (Katsuwonus pelamis L) ASAP PRESTO
}

\author{
Richard Suhartono Anti ${ }^{1}$, Hens Onibala ${ }^{2}$, Eunike Louisje Mongi ${ }^{2}$, Jenki Pongoh $^{2}$, \\ Joyce C.V. Palenewen ${ }^{2}$, Daisy M. Makapedua ${ }^{2}$ \\ ${ }^{1)}$ Mahasiswa pada Program Studi Teknologi Hasil Perikanan FPIK UNSRAT Manado. 95115. \\ ${ }^{2)}$ Staf pengajar pada Program Studi Teknologi Hasil Perikanan FPIK UNSRAT Manado. 95115. \\ E-mail: richardanti55@yahoo.com
}

\begin{abstract}
ABSTRCT
This research objective was to determine the sensory quality and microbial contamination (ALT) of skipjack fish products (Katsuwonus pelamis L) as soon as possible. The treatments tested were 30 and 60 minutes of smoking time, dipresto for 1 hour and then stored at 0,5 and 10 days at room temperature. The results showed that the ALT value was very precise on the 10th day storage of $6.12 \mathrm{x}$ 105 and the lowest value on day 0 was $4.84 \times 102$ while the 5th day of the highest highest $2.15 \times 104$ showed that the product was no longer a recommendation on day 10 because it has exceeded the limit of SNI microbial contamination which is $5.0 \times 105$. The results of sensory evaluation using hedonic scale 1 9 indicated that the highest value of color 7.5, smell 7.4, taste 7.9, and texture texture 7.1.

Keywords: presto smoked skipjack, sensory evaluation, total plate count.

Penelitian ini bertujuan untuk melihat mutu organoleptik dan cemaran mikroba (ALT) pada produk ikan cakalang (Katsuwonus pelamis L) asap presto. Perlakuan yang diujikan adalah lama pengasapan 30 dan 60 menit, dipresto selama 1 jam kemudian disimpan pada 0,5 dan 10 hari pada suhu ruang. Hasil penelitian menunjukan bahwa nilai ALT tertinggi ada pada penyimpanan hari ke 10 yaitu $6.12 \times 105$ dan nilai terendah pada hari ke 0 yaitu $4.84 \times 102$ sedangkan hari ke 5 mendapatkan nilai tertinggi $2.15 \times 104$ ini menunjukan produk tidak lagi direkomendasikan pada hari ke 10 karena telah melebihi batas cemaran mikroba SNI yaitu 5.0 x 105 . Hasil mutu organoleptik menunjukkan bahwa nilai tertinggi warna 7.5 , bau 7.4, rasa 7.9, dan tekstur tekstur 7.1.
\end{abstract}

Kata kunci: ikan cakalang asap, Katsuwonus pelamis L, ikan presto, ALT, suhu ruangan organileptik.

\section{PENDAHULUAN}

Pengolahan hasil perikanan memegang peranan penting dalam kegiatan pascapanen, mengingat hasil perikanan merupakan komoditi yang sifatnya mudah rusak (perishable goods). Oleh karena itu diperlukan penanganan cepat dan tepat untuk menjaga mutunya hingga produk sampai ke tangan konsumen. Sakti, (2012) dalam Liufeto dkk, (2016) menyatakan bahwa industri pengolahan hasil perikanan harus terus didorong dan dikembangkan agar bisa menghasilkan produk yang dicintai konsumen. Produk hasil pengolahan tersebut harus memiliki mutu baik, aman dikonsumsi, tersedia secara berkesinambungan, berdaya saing secara ekonomis dan sesuai dengan selera masyarakat. menurut Sulistijowati,( 2011 ), Pengawetan ikan dengan pengasapan sudah lama dilakukan manusia. Teknologi pengasapan termasuk cara pengawetan ikan yang telah diterapkan secara turun temurun. Istilah pengasapan (smoking) diartikan untuk penyerapan bermacam macam senyawa kimia yang berasal dari asap kayu kedalam daging ikan, disertai dengan setengah pengeringan dan biasanya didahului dengan proses penggaraman. Menurut Saparinto (2007) dalam Hadinoto dan Kolanus (2017) Produk dari presto dimasak dengan menggunakan suhu dan tekanan tinggi, menghasilkan produk dengan tulang yang menjadi lunak sehingga jika dikomsumsi dapat diandalkan sebagai sumber protein dan kalsium bagi anak - anak dan para lansia.prinsip pengolahan dengan cara presto yaitu dengan menggunakan suhu $115{ }^{\circ} \mathrm{C}-120{ }^{\circ} \mathrm{C}$ dan tekanan 1 sampai 2 atmosfir. Suhu dan tekanan tinggi ini dicapai dengan menggunakan alat kukus bertekanan (autoclave) atau dalam skala rumah tangga menggunakan Pressure cooker. Menurut Garnida dkk (2001) dalam Sutomo (2004) pada pengolahan presto pemanasan menyebabkan perubahan beberapa komponen daging ikan. Daging ikan yang mentah mempunyai ciri padat, elastis, mulut berkilau dan rasa mentah. Setalah dipresto, daging 
menjadi lembut, lunak, kenyal, rasa enak, basah dan berciri khas rasa matang.

\section{METODE PENELITIAN}

\section{Bahan dan Alat}

Bahan yang digunakan dalam penelitian ini antara lain bahan baku utama yang dijadikan sampel untuk penelitian ini yaitu ikan cakalang (Katsuwonus pelamis L) sebanyak 12 ekor dengan berat masing-masing ikan 200-250g, dan bahan atau bumbu untuk pembuatan ikan presto yaitu: bawang merah $(20 \mathrm{~g})$, bawang putih $(10 \mathrm{~g})$, jahe $(5 \mathrm{~g})$, kunyit $(5 \mathrm{~g})$, kemiri secukupnya, daun jeruk 1 lembar, daun salam 1 lembar, kemangi secukupnya, garam dapur (20g) cabai (15g) alumunium foil, plastik vakum dan untuk bahan pengujian organoleptik yaitu aqua sebagai penetralisir.

Bahan yang digunakan untuk analisa TPC yaitu alumunium foil, plastik wrapping, tissue, spritus, media nutrient agar, $\mathrm{NaCl} 0,9 \%$, akuades, kertas label, dan alkohol $70 \%$.

Alat yang akan digunakan dalam produk presto yaitu panci presto, kompor, blender, pisau, talenan, loyang, plastik vakum, vakum seeler, tungku pengasapan, pisau. Dan alat yang dipakai untuk uji organoleptik yaitu piring kecil sebagai wadah untuk pengujian sampel ikan dan pulpen. sedangkan alat yang akan digunakan untuk pengujian TPC yaitu, spatula, gunting, hanskun, masker, tabung reaksi, Erlenmeyer, gelas ukur $1000 \mathrm{ml}$, gelas beaker $500 \mathrm{ml}$, cawan petri, incubator, oven, baki, timbangan analitik, Bunsen, autoclave, magnetik stirrer, laminar flow, pipet mikro dan pipet gondok.

\section{Metode Penelitian}

Metode eksperimen adalah metode penelitian yang digunakan untuk mencari pengaruh perlakuan tertentu terhadap yang lain dalam kondisi yang terkendalikan dapat dipahami bahwa penelitian eksperimen adalah penelitian yang dilakukan untuk mengetahui pengaruh pemberian suatu treatment atau perlakuan terhadap subjek penelitian. Jadi penelitian eksperimen adalah kegiatan penelitian yang bertujuan untuk menilai pengaruh suatu perlakuan/tindakan/treatment terhadap pengujian untuk menguji hipotesis tentang ada-tidaknya pengaruh tindakan itu jika dibandingkan dengan tindakan lain.

\section{Tata Laksana Penelitian}

- Ikan cakalang dibeli di pasar Bersehati Manado sebanyak 12 ekor yang berukuran \pm
200-250 Gram. Untuk menjaga mutu, ikan disimpan dalam cool box dan diberi es lalu dibawa ke Laboratorium Penanganan dan Pengolahan Hasil Perikanan untuk diproses. Bersamaan dengan pembelian ikan dilakukan juga pembelian bumbu-bumbu yang akan dipakai sebagai bumbu ikan.

- Ikan disiangi, dimana insang dan isi perut dibuang lalu dicuci dengan air bersih yang mengalir.

- Setelah Ikan dicuci bersih dan disiangi lalu ikan diasapi pada suhu $70-80^{\circ} \mathrm{C}$ selama 30 dan 60 menit.

- Sementara ikan diasapi dilakukan juga pembersihan dan penghalusan bumbu yang sudah disiapkan.

- Dan selesai proses pengasapan lalu ikan akan dilumuri bumbu yang sudah dihaluskan.

- Setelah proses pelumuran bumbu, lalu ikan akan disusun dalam panci presto dengan cara setiap 2 ekor ikan dengan berat $500 \mathrm{~g}$ dibungkus dengan alumunium foil. Cara seperti ini dilakukan mengingat wadah atau panci yang digunakan tidak begitu besar. Untuk pemasakan presto selama $1 \mathrm{jam}$.

- Setelah 1 jam ikan diangkat dan ditiriskan lalu dikemas vakum untuk proses pengujian organoleptik dan Angka Lempeng Total. pada penyimpanan 0,5 dan 10 hari.

\section{Perlakuan}

Perlakuan yang akan dilakukan dalam penelitian ini yaitu:

Perlakuan (A) lama pengasapan:

$$
\text { A1 : } 30 \text { menit; }
$$$$
\text { A2 : } 60 \text { menit. }
$$

Perlakuan (B) lama penyimpanan

B1 : 0 hari Pada suhu ruang;

B2 : 5 hari Pada suhu ruang;

B3 : 10 hari Pada suhu ruang.

\section{Parameter yang di uji}

\section{Analisa Angka Lempeng Total (Modifikasi SNI 01-2332.3-2006)}

1. Sebelum melakukan pengujian cawan petri disterilkan di oven dengan suhu $115^{\circ} \mathrm{C}$ sebelum hari pengujian.

2. Persiapan sampel, Semua peralatan yang akan digunakan dalam pengujian ALT disterilkan terlebih dahulu. sampel yang disediakan diambil $25 \mathrm{~g}$ dari masing-masing ikan yang diasapi 30 dan 60 menit. Lalu sampel ikan diisi di plastik ziplok yang sudah diste- 
rilkan. Disimpan di lemari penyimpanan suhu ruang untuk tahap pengujian.

3. Pembuatan media dengan menggunakan NA yang dihomogenkan.

4. Masukan $\mathrm{NaCl}$ ke dalam Erlenmeyer berukuran $250 \mathrm{ml}$ sebanyak $225 \mathrm{ml}$.

5. Tabung reaksi sebanyak 16 diisi masingmasing dengan $\mathrm{NaCl}$ 0,9\% Sebanyak $9 \mathrm{ml}$.

6. Masukan Erlenmeyer yang berisi media NA, Erlenmeyer yang berisi $\mathrm{NaCl} 0,9 \%$, tabung reaksi yang berisi $\mathrm{NaCl} 0,9 \%$ ke dalam autoclave untuk disterilkan dengan suhu $121^{\circ} \mathrm{C}$ selama kurang lebih $2-3$ jam.

7. Persiapan tempat pengujian.

8. Masukan sampel ikan $25 \mathrm{~g}$ tadi ke dalam Erlenmeyer $250 \mathrm{ml}$ yang sudah berisi $\mathrm{NaCl}$ $0,9 \%$ hingga tercampur.

9. Ambil $1 \mathrm{ml}$ dari Erlenmeyer ke tabung reaksi untuk membuat tingkat pengenceran $10^{-1}-10^{-4}$.

10. Tuangkan $20 \mathrm{ml}$ NA yang masih cair dengan suhu $45^{\circ} \mathrm{C} \pm 1^{\circ} \mathrm{C}$ ke dalam masingmasing cawan petri.

11. Teteskan sampel $1 \mathrm{ml}$ ke cawan petri. Lalu tuangkan $20 \mathrm{ml}$ NA yang masih cair dengan suhu $45^{\circ} \mathrm{C} \pm 1^{\circ} \mathrm{C}$ ke dalam masing-masing cawan petri.

12. Goyangkan cawan petri dengan hati-hati (putar dan goyang ke depan, ke belakang, ke kanan dan ke kiri) sehingga pembenihan tercampur merata dan memadat.

13. Biarkan sampai tercampur dalam cawan petri memadat.

14. Masukan semua cawan petri dengan posisi terbalik ke dalam lemari pengeram pada suhu $37^{\circ} \mathrm{C}$ selama 24 jam

15. Catat pertumbuhan koloni pada setiap cawan petri yang mengandung 25-250 koloni setelah 24 jam

Perhitungan Total Bakteri $=$

$\Sigma$ Koloni x 1 / faktor pengenceran per cawan.

\section{Prosedur Uji Organoleptik (Setyianingsih, 2010)}

Uji kesukaan juga disebut uji hedonik. Panelis dimintakan tanggapan pribadinya tentang kesukaan atau sebaliknya (ketidaksukaan). Disamping panelis mengemukakan tanggapan senang, suka atau sebaliknya, mereka juga mengemukakan tingkat kesukaannya. Tingkattingkat kesukaan ini disebut skala hedonik. Misalnya dalam hal suka dapat mempunyai skala hedonik seperti: amat sangat suka; sangat suka; suka; dan agak suka. Sebaliknya jika tanggapan itu tidak suka dapat mempunyai skala hedonik seperti suka dan agak suka, terdapat tanggapannya yang disebut sebagai netral, yaitu bukan suka tetapi juga bukan tidak suka. Skala hedonik dapat direntangkan atau diciutkan menurut rentangan skala yang dikehendakinya. Skala hedonik dapat juga diubah menjadi skala numerik dengan angka mutu menurut tingkat kesukaan. Dengan data numerik ini dapat dilakukan analisis secara statistik. Penggunaan skala hedonik pada prakteknya dapat digunakan untuk mengetahui perbedaan. Sehingga uji hedonik sering digunakan untuk menilai secara organoleptik terhadap komoditas sejenis atau produk pengembangan.

Prosedur pengujian uji hedonik:

- Persiapan 30 panelis.

- Pengujian dilakukan secara individual dalam booth (bilik pencicip) yang disiapkan.

- Persiapan sampel ikan cakalang asap presto.

- Panelis dipersilahkan masuk ke ruang pengujian setelah semua contoh uji siap diletakan dalam bilik pencicipan.

- Siapkan air penetral.

- Panelis diminta menilai tingkat kesukaan terhadap (kenampakan, warna, rasa, bau) dengan score sheet.

- Selesai dengan penilaian dilanjutkan dengan tabulasi data terhadap semua hasil penilaian.

\section{HASIL DAN PEMBAHASAN}

\section{Analisa Angka Lempeng Total (ALT)}

Pengujian Angka Lempeng Total (ALT) menunjukkan kualitas masa simpan dan adanya kontaminasi silang pada saat proses penyimpanan suhu kamar ikan cakalang asap presto berlangsung. Hasil Analisa penelitian yang sudah didapat diolah dalam bentuk log. Hasil pengamatan ALT pada ikan cakalang asap presto yang disimpan pada suhu ruang dapat dilihat pada Gambar 1.

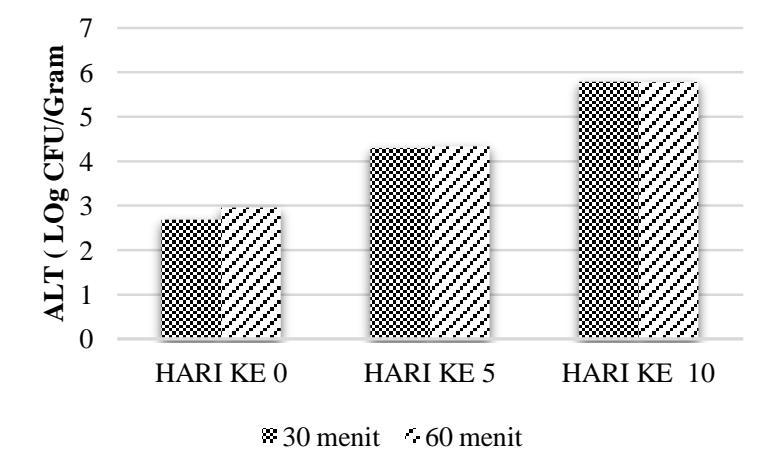

Gambar 1. Hasil Nilai ALT. 
Berdasarkan data tersebut dapat dilihat bahwa nilai ALT pada ikan cakalang asap Presto yang disimpan selama penyimpanan suhu ruang mengalami penurunan kualitas mutu. Berdasarkan data untuk sampel dengan lama pengasapan 30 menit hari ke 0 pada suhu ruang memiliki nilai ALT sebesar $4,8 \times 10^{2} \mathrm{CFU} / \mathrm{g}$, dan untuk pengamatan nilai ALT pada lama pengasapan 60 menit hari ke 0 memiliki nilai $9,2 \times 10^{2} \mathrm{CFU} / \mathrm{g}$. Pada hari ke 5 penyimpanan ikan cakalang asap presto pada suhu ruang nilai ALT sudah mencapai $2,03 \times 10^{4} \mathrm{CFU} / \mathrm{g}$, untuk lama pengasapan 30 menit. Sedangkan nilai ALT pada penyimpanan hari ke 5 untuk pengasapan 60 menit sudah mencapai $2,15 \times 10^{4}$ CFU/g. Sedangkan untuk nilai ALT pada penyimpanan hari ke 10 baik untuk ikan dengan pengasapan 30 dan 60 menit sudah sangat tinggi dengan nilai masing-masing $6,12 \times 10^{5}$ dan $6,03 \times 10^{5}$ dan sudah melebihi batas SNI (2009) yaitu $5,0 \times 10^{5} \mathrm{CFU} / \mathrm{g}$. ini disebabkan karena produk sudah tidak bisa bertahan pada hari ke 10 bahkan bakteri sudah bertumbuh dengan baik di hari ke 10. Kaiang $d k k$. (2016) menyatakan bahwa hasil penelitian pada produk yang dikemas vakum menunjukkan jumlah bakteri lebih rendah, hal ini disebabkan karena tidak tersedianya oksigen untuk kebutuhan metabolism dari bakteri, sehingga bakteri sulit untuk berkembang biak walaupun kadar air yang dikandung produk cukup untuk aktivitas bakteri.

Fardiaz (1989), mengungkapkan bahwa faktor-faktor yang mempengaruhi pertumbuhan mikroorganisme antara lain meliputi intrinsik dan eksterinsik, proses, dan implisit. Faktor intrinsik meliputi PH, aktivitas air (aw), kemampuan mengoksidasi-reduksi, kandungan nutrient, bahan antimikroba dan struktur makanan. Faktor ekstrinsik yang mempengaruhi pertumbuhan mikroorganisme adalah suhu penyimpanan, kelembaban, tekanan gas $\left(\mathrm{O}_{2}\right)$, cahaya dan pengaruh sinar ultraviolet.

\section{Analisa Organoleptik Hedonik}

Analisa organoleptik merupakan suatu cara penilaian menggunakan indera manusia (sensori). Penilaian organoleptik merupakan cara yang paling banyak dilakukan dalam menentukan tingkat kesukaan panelis dari suatu pangan.

Menurut Setyaningsih (2010) analisa organoleptik dengan uji hedonik dapat dilakukan dengan menggunakan score sheet dengan skala dari 1 sampai 9 sebagai nilai tertinggi, dimana angka 1 merupakan nilai terendah dan angka 9 merupakan nilai tertinggi.

Penilaian uji hedonik dilakukan oleh panelis tidak terlatih sebanyak 30 panelis dan diuji dalam tiga kali pengujian. Tapi, pengujian organoleptik dilakukan hanya sampai pada hari ke 5. Ini dikarenakan produk ikan asap cakalang asap presto sudah tidak mampu bertahan pada hari ke 10 karena itu tidak bisa lagi diadakan pengujian.

\section{Warna}

Bila diperhatikan pada gambar 2, ratarata nilai organoleptik warna cakalang asap presto memiliki nilai tertinggi 7,5 untuk pengasapan 60 menit dan 7,3995 untuk 30 menit pengasapan pada penyimpanan 0 hari dan mengalami penurunan nilai pada penyimpanan hari ke 5 yaitu 7,2165 (30 menit pengasapan) dan 7,133 (60 menit pengasapan).

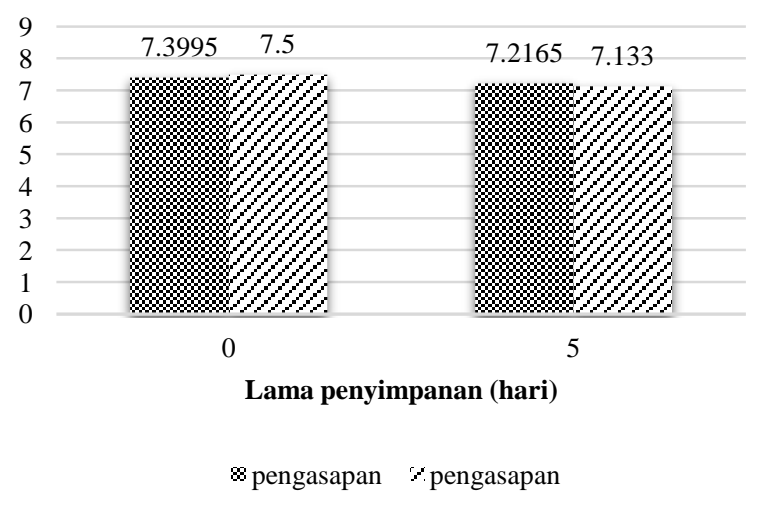

Gambar 2. Histogram nilai rata-rata organoleptik warna.

Hasil analisis sidik ragam menunjukkan bahwa, perbedaan warna ikan cakalang asap presto tidak nyata dipengaruhi oleh perbedaan perlakuan. Sedangkan lama pengasapan dan lama penyimpanan tidak memberikan pengaruh yang nyata terhadap perubahan warna ikan. Sedangkan interaksi sidik ragam juga menunjukkan tidak ada interaksi yang nyata antara faktor lama pengasapan dan lama penyimpanan.

\section{Bau}

Dari gambar 3, nilai rata-rata organoleptik bau memiliki nilai tertinggi 7,4165 pada pengasapan 60 menit pada penyimpanan hari ke 0 dan 7,316 untuk 30 menit pengasapan dan mengalami penurunan nilai pada penyimpanan hari ke 5 yaitu 6,916 (30 menit pengasapan) dan 7,083 (60 menit pengasapan) yang menunjukkan lama penyimpanan mempengaruhi bau. ini didukung oleh analisa sidik ragam yang 
dilakukan yang memberikan pengaruh nyata pada lama penyimpanan seperti pada Tabel 2 .

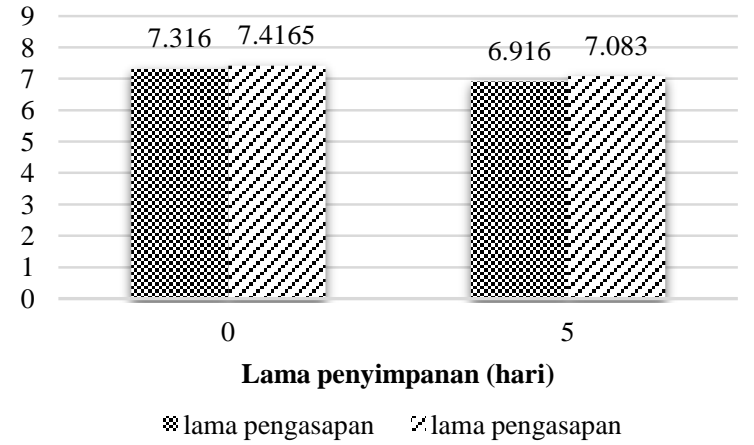

Gambar 3. Histogram nilai rata-rata organoleptik bau.

Hasil analisis sidik ragam diatasi menunjukkan bahwa, perbedaan bau ikan cakalang asap presto tidak nyata dipengaruhi oleh perbedaan perlakuan yang diberikan. Juga dari hasil analisis di atas menunjukkan pula bahwa lama pengasapan tidak memberikan pengaruh yang nyata terhadap perbedaan bau ikan cakalang asap presto. Sedangkan perbedaan bau ikan cakalang asap presto secara nyata dipengaruhi oleh perbedaan lama penyimpanan. Dan tidak ada interaksi yang nyata antara faktor lama pengasapan dan lama penyimpanan.

\section{Rasa}

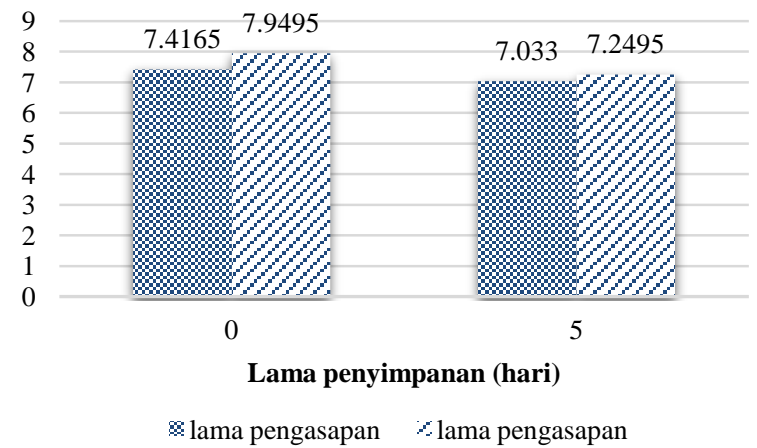

Gambar 4. Histogram nilai rata-rata organoleptik rasa.

Dari gambar 4, nilai rata-rata organoleptik rasa menunjukkan bahwa untuk rasa yang disukai panelis yaitu pada model pengasapan 60 menit dapat dilihat pada histogram, pada penyimpanan hari ke 0 dan hari ke 5 masingmasing memiliki nilai tertinggi 7,9495 untuk hari ke 0 dan 7,2495 untuk hari ke 5. Dan untuk pengasapan 30 menit mendapat nilai $7,4165(0$ hari penyimpanan) dan 7,033 (5 hari penyimpanan) dari nilai ini menunjukkan lama penyimpanan mempengaruhi rasa dari ikan cakalang asap presto dan lama pengasapan. Hasil analisis sidik ragam menunjukkan bahwa, perbedaan rasa ikan cakalang asap presto sangat nyata dipengaruhi oleh perbedaan perlakuan yang diberikan. Adapun perbedaan rasa ikan secara nyata dipengaruhi oleh perbedaan lama pengasapan. Sedangkan perbedaan rasa ikan cakalang asap presto secara sangat nyata dipengaruhi oleh perbedaan lama penyimpanan. Dan tidak ada interaksi yang nyata antara faktor lama pengasapan dan lama penyimpanan.

\section{Tekstur}

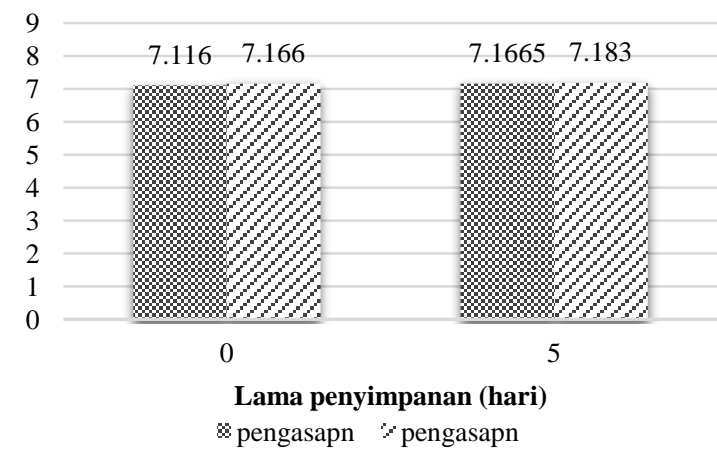

Gambar 5. Histogram nilai rata-rata organoleptik tekstur.

Dari gambar 5, nilai rata-rata organoleptik tekstur di atas menunjukkan tidak ada pengaruh yang signifikan yang berpengaruh terhadap tekstur ikan cakalang asap presto dan sampai pada penyimpanan hari ke 5 masih berkisar pada angka 7 .

Hasil analisis sidik ragam menunjukan bahwa, tekstur ikan cakalang asap presto secara tidak nyata memberikan pengaruh terhadap perbedaan perlakuan yang diberikan. Sedangkan perbedaan lama pengasapan tidak memberikan pengaruh terhadap tekstur ikan cakalang asap presto. Dan perbedaan lama penyimpanan juga memberikan hasil yang tidak nyata terhadap tekstur ikan cakalang asap presto dan interaksi antara lama pengasapan dan lama penyimpanan juga tidak memberikan pengaruh apa-apa antara kedua faktor.

Pada hari ke 10 penyimpanan tidak ada nilai yang didapat karena sudah tidak lagi dilakukan pengujian terhadap sampel produk ikan cakalang asap presto. Ini dikarenakan sampel produk sudah menimbulkan bau yang tidak sedap.

Penelitian sebelumnya yaitu dalam (Paputungan dkk. 2015) mengatakan bahwa nilai organoleptik ikan cakalang asap utuh yang dikemas non vakum di uji dari segi kenampak- 
an, rasa dan bau selama penyimpanan suhu ruang ikan cakalang asap memiliki penurunan nilai pada hari yang ke 2 yang sudah tidak baik dan tidak direkondisikan.

Sedangkan Bawinto $d k k$. (2015) menyatakan bahwa produk ikan tuna asap yang tanpa kemasan pada penyimpanan hari ke 2-4 pada suhu ruang sudah tidak lagi disukai panelis dan sudah tidak termasuk dalam kriteria mutu nilai organoleptik.

Dalam penelitian yang dilakukan Hakim (2016) menyatakan bahwa pemberian konsentrasi madu $30 \%$ mampu mempertahankan nilai rata-rata organoleptik bandeng presto hingga penyimpanan hari ke 4 pada suhu ruang.

\section{KESIMPULAN}

Nilai ALT (Angka Lempeng Total) bakteri ikan cakalang asap presto yang diasapi 30 dan 60 menit dalam waktu penyimpanan 0,5 dan 10 Hari menunjukkan hanya bisa bertahan sampai hari ke 5 saja atau nilai cemaran mikroba menunjukkan bahwa produk ikan yang memenuhi syarat standar batas SNI $\left(5,0 \times 10^{5}\right)$. Dengan nilai hari ke 10 mencapai $6,12 \times 10^{5}$ cemaran mikroba pada hari ke 5 masih dalam batas sedangkan hari ke 10 sudah melebihi batas cemaran mikroba. Ini didukung juga oleh penilaian sensori melalui bau.

Mutu organoleptik ikan cakalang asap presto mendapatkan nilai rata-rata di kisaran 7 dari segi warna, bau, rasa, tekstur baik pengasapan 30 dan 60 menit. Dari hari ke 0 sampai hari ke 5. Untuk penyimpanan hari ke 0 dan 5 masih bisa diterima kelayakannya. Sedangkan hari ke 10 tidak lagi dilakukan pengujian karena sampel produk sudah menimbulkan bau tidak sedap.

\section{DAFTAR PUSTAKA}

Badan Standarisasi Nasional (BSN). 2006a. Cara Uji Mikrobiologi-Bagian 3: Penentuan Angka Lempeng Total (ALT) pada Produk Perikanan: SNI 01-2332.32006. Jakarta.

Bawinto, A. S., Mongi, E., Dan Kaseger B.E. 2015. Analisa kadar air, pH, Organoleptik, Dan Kapang Pada Produk Ikan Tuna (Thunnus Sp) Asap, Di Kelurahan Girian Bawah, Kota Bitung, Sulawesi Utara. Jurnal Media Teknologi Hasil Perikanan. Vol. 3No 2 . UNSRAT. Manado.

Fardiaz, 1989. Mikrobiologi Pangan. Pusat Antar Universitas. Institut Pertanian Bogor.

Hadinoto, S., Dan Kolanus, J.P.M., 2017. Evaluasi Nilai Gizi Dan Mutu Ikan Layang (Decapterus sp) Presto Dengan Penambahan Asap Cair Dan Ragi. Majalah Biam.

Hakim, D. A. 2016 Pengaruh Perendaman Bandeng Presto Dengan Madu Terhadap Nilai Organoleptik dan Jumlah Total Bakteri Pada Penyimpanan Suhu Ruang. SKRIPSI. Fakultas Perikanan dan Kelautan. Surabaya.

Kaiang, D. B.,Montolalu, L., dan Montolalu R. 2016. Kajian Mutu Ikan Tongkol (Euthynnus Affinis) Asap Utuh Yang Dikemas Vakum Dan Non Vakum Selama Dua Hari Penyimpanan Pada Suhu Kamar. Jurnal Media Teknologi Hasil Perikanan. Vol. 4 No 2. UNSRAT. Manado.

Liufeto, D. S., Darmanto, Y, S., Dan Agustini, T. W., 2016. Kualitas Pengolahan Ikan Kayu di Kabupaten Sikka. Prosiding Seminar Nasional kelautan. Madura.

Paputungan, T, S., Wongo, D.,dan Domongilala, L,J. 2015 Kajian Mutu Ikan Cakalang (Katsuwonus Pelamis L) Asap Utuh Yang Dikemas Vakum Dan Non Vakum Selama Proses Penyimpanan Pada Suhu Ruang. Jurnal Media Teknologi Hasil Perikanan. Vol. 3. No 2. UNSRAT. Manado.

Setyaningsih , Dwi., Aprianto, Anton., Dan Sari, Maya, P. 2010. Analisis Sensori Untuk Industri Pangan Dan Agro. IPB Press. Kampus IPB Kencana Bogor.

Sulistijowati, Rieny S., 2011. Mekanisme Pengasapan. UNPAD Press.

Sutomo, A . 2004. Kajian Sifat Fisik Dan Organoleptik Bandeng Presto-Asap Dan Bandeng Asap-Presto Dengan Variasi Konsentrasi Asap Cair Dan Lama Pemasakan. SKRIPSI. Fakultas Teknologi Pertanian Universitas Jember. Jember. 